Научни скуп

Наука и настава у васпитнообразовном контексту

Педагошки факултет у Ужицу

23. октобар 2020.
ISBN 978-86-6191-062-3

DOI 10.46793/STEC20.457V

УДК

378.147:811.111'342.41(497.11)

Стручни чланак стр. 457-474

\author{
Marta V. Veličković ${ }^{*}$ \\ University of Nis, Faculty of Philosophy \\ Jelena R. Danilović-Jeremić* \\ University of Kragujevac, Faculty of Philology and Arts
}

\title{
STANCE MARKERS: AN UNDERDEVELOPED ASPECT OF SERBIAN EFL WRITERS' COMPETENCE ${ }^{* *}$
}

\begin{abstract}
The topic of the current study is the interactional dimension of metadiscourse, as expressed through lexico-grammatical devices in beginner L2 writing of L1 Serbian/L2 English learners. The participants' use of metadiscourse devices was chosen due to its particular relevance for the beginner L2 writing process at the tertiary level. The sample of participants included a total of 70 English language majors attending the University of Niš. The corpus consisted of the students' expository paragraphs collected over a period of nine weeks during the 2019/2020 schoolyear. The taxonomy used in this particular study was that of Biber (2006) and Min et al. (2019), with a particular focus of hedges, stance adjectives, stance adverbs, and stance verbs. The results obtained imply that stance markers deserve a more prominent place in the EFL classroom.
\end{abstract}

Keywords: Stance, academic writing, tertiary education, EFL students, lexico-grammatical devices.

\section{INTRODUCTION}

Metadiscourse, as one of the linguistic means used to convey stance (Jiang, 2017), consists of 'self-reflective' expressions (Min et al., 2019) used to forge a connection between the speaker/writer and the hearer/reader (the interactional dimension of metadiscourse), and between the content/proposition and the hearer/reader (the interactive dimension of metadiscourse). According to the same

\footnotetext{
*marta.velickovic@ filfak.ni.ac.rs

*jelena.jeremic@filum.kg.ac.rs

** The first author would like to state that the paper was prepared as a part of the project Modern Trends in Researching English Linguistics and Anglophone Literature and Culture, conducted at the University of Niš - Faculty of Philosophy (No. 183/1-16-1-01). The second author gratefully acknowledges support from the Ministry of Education, Science and Technological Development of the Republic of Serbia (project grant 178014).
} 
Veličković, M., Danilović-Jeremić, J.: Stance Markers: An Underdeveloped...

Научни скуп „Наука и настава у васпитно-образовном контексту” • стр. 457-474

group of authors, metadiscourse can include hedges, boosters, attitude markers, selfmentions and engagement markers (ibid). The definition of stance as an evaluative attitude expressed by the writer is a difficult one to give. Man \& Chau (2018) based their definition on the work of other more prominent authors, such as Biber (2006), Hyland \& Tse (2005b) and Jiang and Highland (2015), who stated that stance represents the personal feelings, or attitudes, even value judgments expressed by the writer. A more widely acknowledged definition of stance is one that was provided by Biber \& Finegan (1989: 93-94), who indicated that stance is a way for a writer to express their 'value judgment on knowledge', in particular on "its reliability, the mode of knowing, and the adequacy of its linguistic expression", along with "a broad range of personal attitudes".

Much like metadiscourse, stance is used to facilitate reader-writer communication. As a result, it has a potential impact on overall writing quality. For example, Min et al. (2019) claim that metadiscourse features are used twice as much by 'good ESL undergraduate writers' as opposed to those qualified as 'poor'. Stance has also been singled out as a challenging topic for L2/FL learners (Biber, 2006; Hyland, 2005a; Min et al., 2019), and can help determine the level of proficiency or native-like usage of the language adopted by the writer. The more comfortable they are with their L2, the more likely they are to make comments pertaining to how they 'feel' about a particular proposition. Furthermore, providing evaluative judgments by using stance markers is also a means of facilitating interpretation for the reader. This features well within the context of academic writing, which is seen as a form of 'social interaction' that clearly indicates the viewpoint of the writer (Hyland, 2005a). As a result, Man \& Chau (2018) have indicated the need for studies of stance in general, not only for the purpose of benefitting L2 instruction, but for aiding teachers of English for Academic Purposes (EAP). When choosing stance devices, FL writers are not only drawing from the scope of their personal feelings and attitudes, but are also drawing from their cultural background (Jiang, 2017). It is therefore possible to assume that much could be learned from the type and frequency of stance markers in L2 writing.

The influence of cultural background can be seen in situations where the author himself is the source of a proposition. In such circumstances, they may revert to either expressly stating so, emphasizing it in fact, known as 'emphasized averral', or may choose to completely hide their presence, known as 'hidden averral' (Charles (2006) and Hunston (2002), quoted in Jiang, 2017: 87). In addition to stating their own attitude to the source of the proposition, writers can convey their perceptions of the proposition, and establish a rapport with their audience, rendering their content 'plausible' and 'persuasive', in an attempt to anticipate the readers' response. All this is achieved within the scope of their L1 and L2 cultural background.

The academic writing style of the Serbian linguistic community and that of the Anglo-American one differ to a considerable extent, as the former predominantly relies on means of 'hiding' one's presence behind the first person plural pronoun 
Veličković, M., Danilović-Jeremić, J.: Stance Markers: An Underdeveloped... Научни скуп „Наука и настава у васпитно-образовном контексту” • стр. 457-474

'we', whereas this feature is rarely found in the latter. This issue alone further renders studies on stance relevant to EAP and L2/FL writing.

\section{THEORETICAL BACKGROUND}

There are a variety of stance devices that have been studied by EFL researchers. In this study the main focus is on stance adjectives, stance adverbs and stance verbs, as used to indicate epistemic certainty, epistemic likelihood, attitude and emotion, evaluation, ability and willingness, ease or difficulty, causation and effort, style, communication, and desire and intent. The seminal classification stems from Biber's 2006 taxonomy, which is based on semantic categories that include:

\section{1) epistemic certainty}

(e.g., certain, obvious, apparent for adjectives; naturally, surely for adverbs; conclude, find for verbs),

\section{2) epistemic likelihood}

(e.g., likely, probable for adjectives; seemingly, probably for adverbs; seem for verbs),

\section{3) attitude and emotion}

(e.g., sad for adjectives; sadly, fortunately for adverbs; consider, believe for verbs),

\section{4) evaluation}

(e.g., important for adjectives),

\section{5) ability or willingness}

(e.g., able for adjectives),

\section{6) and ease or difficulty}

(e.g., easy, hard for adjectives),

\section{7) hedges}

(e.g. a bit, a little).

This taxonomy was broken down into more detail in Min et al. (2019), and provided the basis for the classification of the lexico-grammatical stance markers identified in this study. The specific categories of analysis can be found in the Results section of this paper.

When it comes to academic writing at the tertiary level in Serbia, the course curriculum for English language majors includes instruction on 
Veličković, M., Danilović-Jeremić, J.: Stance Markers: An Underdeveloped...

Научни скуп „Наука и настава у васпитно-образовном контексту” • стр. 457-474

argumentative/persuasive types of writing. They are introduced to it through expository paragraphs, with the expectation of hedges and stance devices (Min et al., 2019), which play a role in persuading the audience. In the Serbian EFL setting, not a lot of work has been done on determining which linguistic resources students of English use to express evaluation in their writing. A notable exception is the work of Blagojević $(2004 ; 2009 ; 2010 ; 2011 ; 2012)$. However, although focused on academic EFL writing, her work was mostly aimed at academic discourse and research papers, and not as much on the writing of EFL learners at the tertiary level. This notably led to a gap in the field of study.

\section{PREVIOUS RESEARCH}

A variety of stance devices have been studied over the years, in many L1 and L2 combinations, and a range of student/academic writing. Biber \& Finegan (1989) provided an exhaustive overview of overt markers of affect and evidentiality in English. Hyland (1998; 1999; 2000) studied hedges and boosters in argumentative writing. Van Hell et al. (2005) evaluated stance-taking and support in writing, along with genre and modality. Baratta (2009) studied the passive voice as a stance marker. Ryshina-Pankova (2011) determined that FL writers hesitated to use explicit markers of personal opinion. Lee \& Deakin (2016) cited frequent occurrences of interactional metadiscourse in student academic writing. Jiang (2017) studied noun + that clauses as stance markers, Man \& Chau (2018) studied that-clauses, ${ }^{1}$ and Min et al. (2019) studied hedges and stance devices in L2 argumentative writing.

Veličković \& Danilović-Jeremić (2020) studied the scope of stance devices used in a sample of argumentative essays written by a group of L1 Serbian fourthyear university students. They concluded that they focused on achieving distance and objectivity in their academic writing, predominantly using indefinites/impersonal structures, and verbs in the passive voice. Although a substantial use of stance devices can be an indication of more advanced language proficiency, no direct link between the use of stance devices and FL knowledge was determined, which led them to conclude that Serbian EFL learners' choice of stance devices could be taught.

Considering the strong connection between hedges, stance devices and persuasive communication in argumentative writing, we attempted to identify which lexico-grammatical stance devices are preferred by a beginner group of L1 Serbian FL writers. Based on the previously outlined findings, the following research questions were chosen:

${ }^{1}$ This particular group of authors has put forth the claim that phrasal structures are more revealing of stance that are clause structures, which may be the reason behind such choices of linguistic devices as stance markers. 
Veličković, M., Danilović-Jeremić, J.: Stance Markers: An Underdeveloped... Научни скуп „Наука и настава у васпитно-образовном контексту” • стр. 457-474

1. Of all the lexico-grammatical stance devices, notably adjectives, adverbs and verbs, which type did the participants most often use in their expository paragraph writing?

2. Which of the subcategories of stance adjectives, adverbs and verbs did the participants use the most in their expository paragraph writing?

\section{THE METHOD}

Original FL (L1 Serbian) writing was used in this study, in part due to the fact that it does not undergo the same rigorous process of revision and proofreading as academic writing meant for publication. A sample of 218 expository paragraphs were compiled from a group of approximately 70 second-year students, B2 level of proficiency. They are all English language majors at the Faculty of Philosophy, University of Niš. The paragraphs were written and compiled during the fall semester of the 2019/2020 schoolyear. This was the students' first semester learning about academic writing. The students had not received any previous formal instruction on stance, stance markers, or how to use them, nor had any of the feedback that they received during their course mentioned stance.

The paragraphs were collected over a period of nine weeks. They are the product of in-class work, and cover a range of topics: television/the media, dieting/diets, education, holidays, home decoration, physical activity, an item of great significance, family/family life and finally a topic of the students' own choosing. The average number of words per paragraph was $\sim 126$, bringing the total number of analyzed words in this corpus close to 27,500 .

All of the paragraphs were analyzed by the authors. The analysis was based on the classification provided by Biber (2006) and Min et al. (2019). It focused on the following: hedges, stance adjectives, stance adverbs, and stance verbs. These lexico-grammatical stance devices are used to indicate epistemic certainty, epistemic likelihood, attitude and emotion, evaluation, ability and willingness, ease or difficulty, causation and effort, style, communication, and desire and intent. Only examples of stance markers approved by both authors were included in the analysis.

The categories of analysis were based on the work done by Min et al. (2019: $10-12)$ :

Stance adjectives refer the adjectives that express someone's stance, including the following subcategories: ${ }^{2}$

${ }^{2}$ All of the examples provided to illustrate the various categories were extracted from the analyzed expository paragraphs. 
Veličković, M., Danilović-Jeremić, J.: Stance Markers: An Underdeveloped...

Научни скуп „Наука и настава у васпитно-образовном контексту” • стр. 457-474

- Epistemic certainty adjectives: adjectives that show levels of certainty or doubt about the proposition (e.g., apparent, certain, obvious).

There are many more types of these creations, but one thing can be certain, they are all made for the sake of more dramatic and creepy movie scene.

- Epistemic likelihood adjectives: adjectives that imply probability of the idea (e.g., likely, possible, probable).

It also has nonsensical food restrictions that are very damaging to the body and almost impossible to retain for long periods of time.

- Attitude and emotion adjectives: adjectives that indicate writer's feeling about the proposition (e.g., annoyed, disappointed, nervous).

Taking into account that she always learns from my mistakes, it is not surprising that she is always there to listen to me.

- Evaluation adjectives: adjectives that represent writer's judgments about the idea (e.g., appropriate, bad, important).

When I started high school, my father advised me to start studying at least a week before a test since it would be much easier to study a subject in parts rather than all at once.

- Ability or willingness adjectives: adjectives that express the ability and readiness (e.g., able, anxious, careful).

They explained to me how to put myself first in order to be able to love other people around me.

- Ease or difficulty adjectives: adjectives that show evaluation on the idea (e.g., difficult, easy, hard).

At school, for example, I've always tried my best to have good grades, to show her that it isn't that hard.

Stance adverbs refer to the adverbs representing the writer's stance:

- Epistemic certainty adverbs: adverbs that comment on the actuality of ideas (e.g., actually, certainly, definitely).

A fad diet is a type of diet that is only popular for a short amount of time, similar to fashion fads, so their effects are undoubtedly not viable.

- Epistemic likelihood adverbs: adverbs that indicate the probability and likelihood of ideas (e.g., apparently, perhaps, probably). 
Veličković, M., Danilović-Jeremić, J.: Stance Markers: An Underdeveloped... Научни скуп „Наука и настава у васпитно-образовном контексту” • стр. 457-474

Next, our body language is important for our future job because we will probably work with people/children.

- Attitude adverbs: adverbs that show the writer's emotional attitude about a proposition (e.g., amazingly, essentially, fortunately).

There are, surprisingly, non-food stores where you can buy chocolaty snacks too.

- Style adverbs: adverbs that express the writer's manner of speaking (e.g., according to, generally, usually).

Scientific programs generally attract people who are educated and who want to broaden their knowledge in a particular field.

Stance verbs include the particular verbs that show the writer's stance, including the following:

- Epistemic certainty verbs: verbs that express conviction or certainty (e.g., conclude, notice, prove).

There are three zodiac signs which are believed to have a large number of positive traits.

- Epistemic likelihood verbs: verbs that imply questionable assertions (e.g., assume, guess, seem).

Vlach holidays and rituals seem very odd when compared with more common, place holidays but are, in my opinion, just as jolly.

- Attitude verbs: verbs that show the writer's personal attitudes (e.g., agree, expect, feel).

I find it truely relaxing when I'm in a new place surrounded by new people.

- Desire and intention verbs: verbs that express the writer's desire, decision, and intention about the idea (e.g., decide, hope, want).

In conclusion, these wildfires have brought a lot of pain and torment to the people of Australia, but we all hope that they will have enough strength to overcome the obstacles.

- Causation and effort verbs: causation, modality, and effort verbs that indicate the facilitated action (e.g., enable, mange, require).

This allows you to gang up with other players and complete quests together.

- Communication verbs: verbs that describe speech acts, communicative activities and source of information about the proposition (e.g., claim, insist, say). 
Veličković, M., Danilović-Jeremić, J.: Stance Markers: An Underdeveloped... Научни скуп „Наука и настава у васпитно-образовном контексту” • стр. 457-474

Secondly, the say that the lyrics is too violent and maybe sometimes Satanistic.

\section{THE RESULTS}

For clarity, research questions 1 and 2 will be discussed simultaneously.

Of the 218 analyzed paragraphs, as many as $94(\sim 43.12 \%)$ contained no examples of stance devices, indicating the unmistakably low level at which this group of participants manages metadiscourse.

The most frequently used type of lexico-grammatical stance device were stance adjectives $(\sim 44.17 \%)$. They are followed by stance adverbs $(\sim 27.18 \%)$, and a close third are stance verbs $(\sim 26,21 \%)$. By far the least frequently used stance device were hedges $(\sim 2.4 \%)$.

Table 1. The frequency of occurrence of the analyzed stance devices

\begin{tabular}{lc}
\hline Stance device & $\begin{array}{c}\text { percentage of total number } \\
\text { of stance devices }(100 \%)\end{array}$ \\
\hline Stance adjectives & $\sim 44.17 \%$ \\
Stance adverbs & $\sim 27.18 \%$ \\
Stance verbs & $\sim 26,21 \%$ \\
Hedges & $\sim 2.4 \%$ \\
\hline
\end{tabular}

The results can further be broken down in the following manner.

Of the types of stance adjectives identified by Min et al. (2019), the most frequently occurring type were adjectives that represent the writer's judgment $(\sim 48.26 \%)$. The most frequently used stance adjective in particular belongs to this group: the adjective important $(\sim 25.27 \%)$. The second most frequently used type are stance adjectives that show evaluation of an idea $(\sim 26.37 \%)$, of which the most frequently occurring adjective was difficult/hard ( 17.58\%). It is also the second most frequently used stance adjective. The third most frequently used type were stance adjectives that show levels of certainty or doubt $(\sim 10.93 \%)$, of which the most frequently occurring adjectives were certain and apparent $(\sim 2.19 \%)$. The fourth were stance adjectives indicating the writer's ability or readiness $(\sim 8.78 \%)$, of which the most frequently occurring adjective was able $(\sim 7.69 \%)$. This group is followed by adjectives that imply probability, $(\sim 5.48 \%)$, with impossible having the highest occurrence rate $(\sim 4.39 \%)$. And finally, only one adjective was found that indicates the writer's feelings, $s a d$, with a frequency of $\sim 1.09 \%$. 
Veličković, M., Danilović-Jeremić, J.: Stance Markers: An Underdeveloped...

Научни скуп „Наука и настава у васпитно-образовном контексту” • стр. 457-474

Table 2. Frequency of occurrence of the various stance adjectives

\begin{tabular}{lc}
\hline Stance adjectives & $\begin{array}{c}\sim \text { percentage of all stance } \\
\text { adjectives used }(100 \%)\end{array}$ \\
\hline Adjectives that represent the writer's judgment & $\sim 48.26 \%$ \\
Adjectives that show evaluation of an idea & $\sim 26.37 \%$ \\
Adjectives that show certainty or doubt & $\sim 10.93 \%$ \\
Adjectives that express the writer's ability & $\sim 8.78 \%$ \\
and readiness & $\sim 5.48 \%$ \\
Adjectives that imply probability of the idea & $\sim 1.09 \%$ \\
Adjectives that indicate the writer's feelings & \\
\hline
\end{tabular}

Table 3. provides an overview of the all the different adjectives used in the expository paragraphs.

Table 3. The frequency of occurrence of particular examples of stance adjectives ${ }^{3}$

\begin{tabular}{lc}
\hline Stance adjective & $\begin{array}{c}\sim \text { percentage of individual type } \\
\text { of used stance adjectives }(100 \%)\end{array}$ \\
\hline Adjectives that represent the writer's judgment & $\sim 25.27 \%$ \\
IMPORTANT & $\sim 6.59 \%$ \\
GOOD/BEST & $\sim 5.49 \%$ \\
BAD & $\sim 3.29 \%$ \\
ESSENTIAL & $\sim 1.09 \%$ \\
NATURAL, DISAPPOINTING, & \\
SURPRISING, VITAL, ANNOYING, & \\
EXCELLENT, SURPRISING & $\sim 17.58 \%$ \\
Adjectives that show evaluation of an idea & $\sim 8.79 \%$ \\
DIFFICULT/HARD/HARDEST & $\sim 2.19 \%$ \\
EASIER/EASY & $\sim 1.09 \%$ \\
Adjectives that show certainty or doubt & \\
APPARENT, CERTAIN & \\
OBVIOUS, SURE & $\sim 7.69 \%$ \\
Adjectives that express the writer's ability & $\sim 1.09 \%$ \\
and readiness & \\
ABLE & $\sim 4.39 \%$ \\
UNABLE & $\sim 3.29 \%$ \\
Adjectives that imply probability of the idea & $\sim 1.09 \%$ \\
IMPOSSIBLE &
\end{tabular}

${ }^{3}$ Note: the approximate percentages indicate the overall frequency of the occurrence of each lexico-grammatical device. 
Veličković, M., Danilović-Jeremić, J.: Stance Markers: An Underdeveloped... Научни скуп „Наука и настава у васпитно-образовном контексту” • стр. 457-474

Adjectives that indicate the writer's feelings

SAD $\sim 1.09 \%$

Of the types of stance adverbs identified by Min et al. (2019), the most frequently occurring type were adverbs that express the writer's manner of speaking $(\sim 42.84 \%)$. The most frequently used stance adverb in particular belongs to this group: the adverb usually $(\sim 30.35 \%)$. The second most frequently used type were stance adverbs that show the writer's emotional attitude $(\sim 23.17 \%)$, of which the most frequently occurring adverb was basically $(\sim 7.14 \%)$. However, after usually, the second most frequently used stance adverb in general was probably, $(\sim 14.28 \%)$, which belongs to the group of adverbs that indicate the probability and likelihood of an idea (frequency of occurrence $\sim 16.06 \%$, the lowest among the adverbs).

Table 4. Frequency of occurrence of the various stance adverbs

\begin{tabular}{lc}
\hline Stance adverbs & $\begin{array}{c}\sim \text { percentage of all stance } \\
\text { adverbs used }(100 \%)\end{array}$ \\
\hline $\begin{array}{l}\text { Adverbs that express the writer's manner } \\
\text { of speaking }\end{array}$ & $\sim 42.84 \%$ \\
$\begin{array}{l}\text { Adverbs that show the writer's emotional } \\
\text { attitude about a proposition }\end{array}$ & $\sim 23.17 \%$ \\
$\begin{array}{l}\text { Adverbs that comment on the actuality } \\
\text { of ideas }\end{array}$ & $\sim 17.82 \%$ \\
$\begin{array}{l}\text { Adverbs that indicate the probability } \\
\text { and likelihood of ideas }\end{array}$ & $\sim 16.06 \%$ \\
\hline
\end{tabular}

Table 5. provides an overview of the all the different adverbs used in the expository paragraphs.

Table 5. The frequency of occurrence of particular examples of stance adverbs ${ }^{4}$

\begin{tabular}{lc}
\hline Stance adverb & $\begin{array}{c}\sim \text { percentage of individual type } \\
\text { of used stance adverbs (100\%) }\end{array}$ \\
\hline $\begin{array}{l}\text { Adverbs that express the writer's manner } \\
\text { of speaking }\end{array}$ & \\
USUALLY & $\sim 30.35 \%$ \\
GENERALLY & $\sim 7.14 \%$ \\
ACCORDING TO & $\sim 5.35 \%$ \\
Adverbs that show the writer's emotional & \\
attitude about a proposition & $\sim 7.14 \%$ \\
BASICALLY & $\sim 3.57 \%$ \\
TRULY & $\sim 1.78 \%$ \\
MASTERFULLY, DRASTICALLY, & \\
\hline
\end{tabular}

${ }^{4}$ Note: the approximate percentages indicate the overall frequency of the occurrence of each lexico-grammatical device. 
Veličković, M., Danilović-Jeremić, J.: Stance Markers: An Underdeveloped... Научни скуп „Наука и настава у васпитно-образовном контексту” • стр. 457-474

\begin{tabular}{lc}
\hline Stance adverb & $\begin{array}{c}\sim \text { percentage of individual type } \\
\text { of used stance adverbs }(100 \%)\end{array}$ \\
\hline $\begin{array}{l}\text { SURPRISINGLY, NORMALLY, SADLY, } \\
\text { FORTUNATELY, ESSENTIALLY }\end{array}$ \\
\hline $\begin{array}{l}\text { Adverbs that comment on the actuality } \\
\text { of ideas }\end{array}$ \\
SURELY, NATURALLY & $\sim 5.35 \%$ \\
EXPECTEDLY, ACTUALLY, & $\sim 1.78 \%$ \\
UNDOUBTEDLY, OBVIOUSLY & \\
Adverbs that indicate the probability & \\
and likelihood of ideas & $\sim 14.28 \%$ \\
PROBABLY & $\sim 1.78 \%$ \\
SEEMINGLY &
\end{tabular}

Of the types of stance verbs identified by Min et al. (2019), the most frequently occurring type were verbs that describe speech acts, communicative activities and source of information $(\sim 46.25 \%)$. The most frequently used stance verb from this particular group is the verb say $(\sim 5.55 \%)$. However, one of the two most frequently used stance verbs belongs to a second group, that of verbs indicating causation, modality or effort verbs ( 27.75\%): the stance verb manage $(\sim 9.25 \%)$. The third most frequently occurring type were stance verbs that show the writer's personal attitude $(\sim 12.95 \%)$, of which the most frequently occurring verb was consider $(\sim 7.40 \%)$. The fourth were stance verbs that imply questionable assertions $(\sim 11.1 \%)$. The second most frequently occurring stance verb belongs to this group: the verb seem $(\sim 9.25 \%)$. And finally, only one verb was found that expresses the writer's desire, decision and intention, hope, with a frequency of $\sim 1.85 \%$.

Table 6. Frequency of occurrence of the various stance verbs

\begin{tabular}{lc}
\hline Stance verbs & $\begin{array}{c}\text { percentage of all stance } \\
\text { verbs used }(100 \%)\end{array}$ \\
\hline Communication verbs & $\sim 46.25 \%$ \\
Verbs indicating causation, & $\sim 27.75 \%$ \\
modality, effort verbs & $\sim 12.95 \%$ \\
Verbs that show the writer's personal & $\sim 11.1 \%$ \\
attitude & $\sim 1.85 \%$ \\
Verbs that imply questionable assertions & Verbs that express the writer's desire, \\
decision, intention & \\
\hline
\end{tabular}

Table 7. provides an overview of the all the different verbs used in the expository paragraphs. 
Veličković, M., Danilović-Jeremić, J.: Stance Markers: An Underdeveloped... Научни скуп „Наука и настава у васпитно-образовном контексту” • стр. 457-474

Table 7. The frequency of occurrence of particular examples of stance verbs ${ }^{5}$

\begin{tabular}{lc}
\hline Stance verb & $\begin{array}{c}\sim \text { percentage of individual type } \\
\text { of used stance verbs (100\%) }\end{array}$ \\
\hline Communication verbs & $\sim 5.55 \%$ \\
SAY & $\sim 3.70 \%$ \\
DESCRIBE, MAINTAIN, & \\
SHOWCASE/SHOW & \\
SUGGEST, RECOMMEND, REPORT, & $\sim 1.85 \%$ \\
BELIEVE, ESTEEMED, QUESTION, & \\
RANKED, JUDGED, EXPLAIN, & \\
PROMISE, STATE, CONCLUDE, & \\
DETERMINE, CLAIM & \\
Verbs that indicate causation, modality, & \\
effort verbs & $\sim 9.25 \%$ \\
MANAGE & $\sim 3.70 \%$ \\
ALLOW & \\
INDUCE, EASE, LET, REQUIRE, & $\sim 1.85 \%$ \\
OVERCOME, FORCES, ENABLE, & \\
DEMAND & \\
Verbs that show the writer's personal attitude & $\sim 7.40 \%$ \\
CONSIDER & $\sim 3.70 \%$ \\
FIND & $\sim 1.85 \%$ \\
BELIEVE & \\
Verbs that imply questionable assertions & $\sim 9.25 \%$ \\
SEEM & $\sim 5.55 \%$ \\
CONSIDER & \\
Verbs that express the writer's desire, & $\sim 1.85 \%$ \\
decision, intention & \\
HOPE & \\
\hline
\end{tabular}

Of all the lexico-grammatical devices that were analyzed it the corpus, the fewest were hedges with only five in total. They accounted for merely $\sim 2.4 \%$ of all the identified stance devices. The most frequently example was $a$ bit which accounted for $80 \%$ of all the hedges used in the paragraphs, and a little, which accounted for $20 \%$.

\footnotetext{
${ }^{5}$ Note: the approximate percentages indicate the overall frequency of the occurrence of each lexico-grammatical device.
} 
Veličković, M., Danilović-Jeremić, J.: Stance Markers: An Underdeveloped...

Научни скуп „Наука и настава у васпитно-образовном контексту” • стр. 457-474

\section{DISCUSSION}

Based on the results, stance adjectives occurred almost twice as much as stance adverbs and stance verbs, while the frequency of occurrence of stance adverbs and verbs is almost the same. Even though the frequency of occurrence of adjectives is greater than that of adverbs, the number of tokens for each is quite similar, 23 to 20 . Overall, the range of individual words that are used to convey stance is low. This particular group of beginner writers tended to prefer vocabulary items which are to a considerable extent a part of their everyday vocabulary: the adjective important, the adverb usually, and the verbs say, manage and seem. By not using more diverse stance makers, they give off the impression of hiding both their presence and their attitudes towards the propositions, and never clearly state the sources of the propositions.

Considering that hedges, as indicated by Hyland (1994) and Min et al. (2019), are devices which have proven to be particularly difficult for EFL writers, our findings are not surprising. As suggested by Hinkel (2004) and Min et al. (2019), the diversity of their functions, the potential influence of L1 on their use, and the extent to which they permeate academic and/or business writing might indicate that their analysis should be the subject matter of a separate study. In this particular case their frequency and range are too low to allow either a quantitative or qualitative analysis.

In the case of stance devices, it is possible to assume that linguistic proficiency is a pertinent issue, at least to a certain extent; however, we are inclined to consider this can account for only a fraction of the results. In our view, their overall performance is more likely the result of a feeling that it is inappropriate to 'insert themselves' in such a way in their writing, perhaps as a result of the impersonal 'shared responsibility' style of writing in their L1. Furthermore, not having benefited from any explicit instruction on stance, or implicit for that matter, and since their coursebook makes no reference to it, they may not have even considered it a relevant option. It seems likely that the detected occurrences of stance devices are more a reflection of the writers' own personal budding styles than that of an existing awareness of stance.

The current findings to an extent do compare to those of Veličković \& Danilović-Jeremić (2020). A lack of variety or range of linguistic devices was noted in both studies without, however, an indication of the extent to which their exclusion was voluntary. The predominant impersonal style previously recorded by these authors is not uncommon in FL writing. Similar findings have been reported by Biber \& Finegan (1989), Hyland (2012), and Reilly et al. (2005), irrespective of the written material they were analyzing. In brief, the so-called 'faceless stance' is an increasingly more present feature of FL writing.

Yet another point needs to be taken into consideration. In a study of six different fields Jiang (2017) outlined some of the main features of the 'soft' 
Veličković, M., Danilović-Jeremić, J.: Stance Markers: An Underdeveloped...

Научни скуп „Наука и настава у васпитно-образовном контексту” • стр. 457-474

sciences, i.e. the humanities and social sciences. These include, but are not limited to: their being discursive in nature; that writers in these sciences are more likely to make their presence 'felt' by clearly providing comments on the content/propositions; that they rely considerably on 'cognitive understanding', that in these sciences most claims rely on personal interpretations which leave writers more freedom to provide their judgments than in the 'hard' sciences; that arguments in the 'soft' sciences are 'necessarily explicitly interpretative', etc. In such a context, the lack of stance devices in the FL writing of the studied population must be addressed appropriately, and explicitly. As part of their tertiary education, English language majors are expected to write term papers and a bachelor thesis; the majority of them will go on to write their master's thesis, some even doctoral dissertations. As a result, any instruction they receive, which so far has focused mostly on form, must also make room and make time to address content with a view to the writer's perspectives on the content and its sources, and address their relationship with the audience. As previously indicated, both Lee \& Deakin (2016) and Min et al. (2019) stated that the increased use of stance devices is a recognized quality of 'good ESL undergraduate writers', hence our teaching must reflect this requirement as well. As Hyland (2012) and Kärkkäinen (2003) both stated, allowing personal perceptions into a body of writing is a choice, and EFL learners need to be made aware that such a choice is available to them, irrespective of what they may perceive as the "confines" of the academic genre.

These assumptions leave room for specific pedagogical implications. It is not simply an issue of teaching FL writers to include more stance devices in their writing. A delicate balance must be established between the features of 'soft' sciences and the requirements of academic writing, primarily that of the "convention of impersonality'. If our goal is to make our students more proficient writers, wellversed in the characteristics of academic writing in their particular 'soft' science, an initial step might be to introduce well-worded examples from naturally occurring language produced by their own peers at the initial stages of learning to write, much at the same time as the information pertaining to paragraph structure. This may require certain 'adaptations' of the existing coursebooks, but overall could prove beneficial. This would mean relying on the 'genre approach' when teaching FL writing (Gee in Luchini, 2002). This approach is mostly based on modelling other people's writing (Harmer, 2004; Nunan, 1989), which when analyzed, could be used as a model of the type, number and overall function of the stance devices used. 
Veličković, M., Danilović-Jeremić, J.: Stance Markers: An Underdeveloped...

Научни скуп „Наука и настава у васпитно-образовном контексту” • стр. 457-474

\section{CONCLUSION AND IMPLICATIONS \\ FOR FURTHER RESEARCH}

The way to challenge the persistent lack of stance devices lies in both adaptations of the teaching process/material and in increasing the scope of research. One of the issues that should be addressed is the fact that existing work (Blagojević, 2004; 2009; 2010; 2011; 2012 and Veličković \& Danilović-Jeremić, 2020) on academic discourse and stance devices in the Serbian linguistic environment has so far been descriptive in nature rather than interpretative. It would be quite useful, to the learners, to their teachers, as well as to researchers themselves, to take a longitudinal look at how and whether the use of particular stance markers changes over time and in what direction. The influence of explicit instruction could also be monitored and quantified. Furthermore, additional variables should be included in any further analyses, such as L2 proficiency and writing competence. As Man \& Chau (2018) indicated, differences in the linguistic devices could occur as a result of various topics, which means that a controlled writing task could also potentially be included in future studies.

\section{References}

Baratta, A. M. (2009). Revealing stance through passive voice. Journal of Pragmatics, 41(7), 1406-1421, https://doi.org/10.1016/j.pragma.2008.09.010.

Biber, D. (2006). University language: A corpus-based study of spoken and written registers, vol. 23. Amsterdam: John Benjamins, https://doi.org/10.1075/scl.23.

Biber, D. \& Finegan, E. (1989). Styles of stance in English: Lexical and grammatical marking of evidentiality and affect. Text, 9(1), 93-124, https://doi.org/10.1515/text.1.1989.9.1.93.

Blagojević, S. (2010). The Manifestation of Authorial Presence in Academic Writing as a Sign of Cultural Identity. Cambridge Scholar Publication, Identity Issues: Literary and Linguistic Landscapes', Cambridge, 251-265.

Blagojević, S. (2004). Metadiscourse in Academic Prose: a Contrastive Study of Academic Articles Written in English by English and Norwegian Native Speakers. Kalbu Studijos, 5, 60-67.

Blagojević, S. (2009). Expressing attitudes in academic research articles written by English and Serbian authors. Facta Universitatis, Series: Linguistics and Literature, 7(1), 63-73.

Blagojević, S. (2011). „Mi” kao „mi” ili „mi” kao ,ja”: prvo lice množine kao eksponent autorovog prisustva u akademskom pisanom diskursu. Zbornik Matice srpske za filologiju i lingvistiku, 54, 207-218. 
Veličković, M., Danilović-Jeremić, J.: Stance Markers: An Underdeveloped...

Научни скуп „Наука и настава у васпитно-образовном контексту” • стр. 457-474

Blagojević, S. (2012). O engleskom i srpskom akademskom diskursu. Niš: Filozofski fakultet.

Harmer, J. (2004). How to Teach Writing. Essex: Longman.

Hinkel, E. (2004). Teaching academic ESL writing: Practical techniques in vocabulary and grammar. London/Mahwah/New Jersey: Lawrence Erlbaum and Associates.

Hyland, K. (1994). Hedging in academic writing and EAP textbooks. English for Specific Purposes, 13, 239-256, https://doi.org/10.1016/0889-4906(94)90004-3.

Hyland, K. (2005a). Stance and engagement: A model of interaction in academic discourse. Discourse Studies, 7(2), 173-192. DOI 10.1177/1461445605050365.

Hyland, K. (1998). Hedging in scientific research articles. Amsterdam: John Benjamins. https://doi.org/10.1075/pbns.54.

Hyland, K. (1999). Talking to students: Metadiscourse in introductory coursebooks. Journal of English for Specific Purposes, 18(1), 3-26, https://doi.org/10.1016/ S0889-4906(97)00025-2.

Hyland, K. (2000). Disciplinary discourses: Social interactions in academic writing. London: Longman.

Hyland, K. (2012). Undergraduate Understandings: Stance and Voice in Final Year Reports. In K. Hyland \& C. S. Guinda (eds.): Stance and Voice in Written Academic Genres, 134-150. London: Palgrave Macmillan, https://doi.org/10.1057/ 9781137030.

Hyland, K. \& Tse, P. (2005b). Evaluative that constructions: Signalling stance in research abstracts. Functions of Language, 12(1), 39-63. DOI $\underline{10.1075 / \text { fol.12.1.03hy. }}$

Jiang, K. (2017). Stance and voice in academic writing: The "noun + that" construction and disciplinary variation. International Journal of Corpus Linguistics, 22(1), 85106. DOI 10.1075/ijc1.22.1.04jia.

Jiang, K. F. \& Hyland, K. (2015). 'The fact that': Stance nouns in disciplinary writing. Discourse Studies, 17(5), 529-550. DOI 10.1177/1461445615590719.

Kärkkäinen, E. (2003). Epistemic Stance in English Conversation: A description of its interactional functions, with a focus on I think. Amsterdam/Philadelphia: John Benjamins Publishing Company, https://doi.org/10.1075/pbns.115.

Lee, J. \& Deakin, L. (2016). Interaction in L1 and L2 undergraduate student writing: Interactional metadiscourse in successful and less successful argumentative essays. Journal of Second Language Writing, 33, 21-34, https://doi.org/10.1016/ j.jslw.2016.06.004.

Luchini, P. L. (2002). Evaluation of Teachers' Methodology of Writing Skill Teaching: A Case Study. The Linguistics Association of Korea Journal, 10(4), 211-232.

Man, D. \& Chau, M. H. (2018). Learning to evaluate through that-clauses: Evidence from a longitudinal learner corpus. Journal of English for Academic Purposes. DOI https://doi.org/10.1016/j.jeap.2018.11.007. 
Veličković, M., Danilović-Jeremić, J.: Stance Markers: An Underdeveloped...

Научни скуп „Наука и настава у васпитно-образовном контексту” • стр. 457-474

Min, S., Paek, J. K. \& Kang, Y. (2019). Exploring the use of hedges and stance devices in relation to Korean EFL learners' argumentative writing qualities. English Teaching, 74(1), 3-23. DOI 10.15858/engtea.74.1.201903.3.

Nunan, D. (1989). Designing Tasks for Communicative Classroom. Cambridge: Cambridge University Press. DOI https://doi.org/10.1017/S0272263100009578.

Reilly, J., Zamoraa, A. \& McGiverna, R. F. (2005). Acquiring perspective in English: the development of stance. Journal of Pragmatics, 37, 185-208, https://doi.org/10.1016/j.pragma.2004.08.010.

Ryshina-Pankova, M. (2011). Developmental changes in the use of interactional resources: Persuading the reader in FL book reviews. Journal of Second Language Writing, 20, 243-256, https://doi.org/10.1016/j.jslw.2011.05.011.

van Hell, J. G., Verhoeven, L., Tak, M. \& van Oosterhout, M. (2005). To take a stance: a developmental study of the use of pronouns and passives in spoken and written narrative and expository texts in Dutch. Journal of Pragmatics, 37(2), 239-273, https://doi.org/10.1016/j.pragma.2004.08.004.

Veličković, M. \& Danilović-Jeremić, J. (2020). Taking a stand: stance strategies in L1 Serbian English learners' expository essays. Journal of Teaching English for Specific and Academic Purposes, 8(2), 147-158, https://doi.org/10.22190/ JTESAP2002147V. 
Veličković, M., Danilović-Jeremić, J.: Stance Markers: An Underdeveloped...

Научни скуп „Наука и настава у васпитно-образовном контексту” • стр. 457-474

\section{Марта В. Величковић}

Универзитет у Нишу, Филозофски факултет

Јелена Р. Даниловић-Јеремић

Универзитет у Крагујевцу, Филолошко-уметнички факултет

\section{ИЗРАЖАВАЊЕ СТАВОВА У ПИСАЊУ: НЕДОВОЉНО РАЗВИЈЕНА ВЕШТИНА КОД УЧЕНИКА ЕНГЛЕСКОГ ЈЕЗИКА КАО СТРАНОГ}

\section{Резиме}

Циљ овог рада је испитивање интеракцијске димензије метадискурса, изражене лексичко-граматичким формама, код ученика енглеског језика као страног. Употреба одговарајућих форми којима се изражава став говорника значајна је, у истраживачком смислу, јер се може довести у везу са наставом академског писања на универзитетском нивоу. У истраживању је учествовало 70 студената енглеског језика који наставу похађају на Филозофском факултету у Нишу. Корпус студентских радова (тачније, пасуса), прикупљен је током девет недеља током академске 2019/2020. године док је анализа прикупљеног материјала спроведена на основу радова Бајбер (2006) и Мин и сар. (2019). Анализа је укључивала идентификацију форми које служе за ограђивање говорника, као и врста речи којима се изражавају његови ставови (нпр. придеви, прилози и сл.). Добијени резултати указују да је поменутим језичким формама потребно посветити више пажње у настави енглеског језика.

Кључне речи: ставови, академско писање, лексичко-граматичке форме, ученици енглеског језика као страног. 